Престенотичне розширення проксимальних відділів шлунка як предиктор розвитку гастроезофагеального рефлюксу у віддаленому періоді після лапароскопічної гастроплікаціі

\author{
С. І. Саволюк, В. М. Лисенко, М. Ю. Крестянов, Д. С. Завертиленко, \\ А. Ю. Глаголева, Є. К. Кругляк \\ Національна медична академія післядипломної освіти імені П. Л. Шупика, м. Київ
}

\title{
Prestenotic dilation of proximal parts of stomach as a predictor for development of gastroesophageal reflux in late period after laparoscopic gastroplication
}

\author{
S. I. Savoliuk, V. M. Lysenko, M. Yu. Krestianov, D. S. Zavertylenko, \\ A. Yu. Glagolieva, E. K. Krugliak \\ Shupyk National Medical Academy of postgraduate Education, Kyiv
}

Реферат

Мета. Оцінка безпосередніх та віддалених результатів лапароскопічної гастроплікації (ЛГП) та аналіз предикторів несприятливих наслідків баріатричної операції.

Матеріали і методи. Дослідження проведено на основі результатів обстеження та хірургічного лікування 79 хворих 3 ожирінням та метаболічним синдромом, яким була виконана ЛГП на базах кафедр хірургії та судинної хірургії НМАПО імені П. Л. Шупика за період з 2015 по 2018 р.

Результати. За результатами повторних досліджень, проведених через один рік після виконаного хірургічного втручання, констатували зниження індексу маси тіла, покращення показників глікемії, ліпідограми, нормалізацію артеріального тиску, зменшення частоти апное уві сні. За даними повторної рентгеноскопії 3 контрастуванням верхніх відділів травного каналу, проведеної через 6 міс після ЛГП, у 20 (25,3\%) пацієнтів визначили нерівномірне звуження шлункової трубки вище кута шлунка. Через 12 міс зафіксували рентгенологічні ознаки значного розширення сформованої шлункової трубки, дна та кардіального відділу шлунка, збільшення кута Гіса, наявність гастроезофагеального рефлюксу контрастної рідини, а 2 пацієнти мали ознаки аксіальної кардіальної грижі стравохідного отвору діафрагми (ГСОД). Водночас у 20,2\% пацієнтів спостерігали симптоми гастроезофагеальної рефлюксної хвороби (ГЕРХ) із суттєвим погіршенням якості життя.

Висновки. ЛГП є потенційно безпечною та ефективною операцією, після якої значно і стійко знижується маса тіла. Однак у 20,2\% пацієнтів виникають такі ускладнення, як ГЕРХ та рефлюкс-езофагіт, протягом 12 міс після ЛГП, виконаної 3 метою хірургічного лікування ожиріння. Виникнення зазначених віддалених ускладнень є наслідком часткового стенозу в ділянці кута шлунка, що призводить до розвитку престенотичного розширення проксимальних відділів шлунка.

ключові слова: ожиріння; метаболічний синдром; лапароскопічна гастроплікація; рефлюкс -езофагіт.

Abstract

Objective. Estimation of immediate and late results of laparoscopic gastroplication (LGP) and analysis of predictors of unfavorable outcomes of bariatric operation.

Materials and methods. The investigation was conducted on background of results of examination and surgical treatment on 79 patients, suffering obesity and metabolic syndrome, to whom LGP was accomplished on the cathedral bases of the Shupyk NMAPE Department of Surgery and Vascular Surgery in 2015 - 2018 yrs.

Results. In accordance to secondary investigations, done in one year after the operative intervention, the body mass index lowering/ improvement of the glycemia and lipidogram indices, as well as the arterial pressure normalization and reduction of the apnoe rate while sleeping were registered. In accordance to data of secondary roentgenoscopy with contrasting of the foregut, conducted in 6 mo after LGP, in 20 (25.3\%) patients irregular narrowing of a gastric tube higher than gastric angle was registered. In 12 mo roentgenological signs of significant widening of the gastric tube, formatted of fundus and cardia were seen, as well as the angle of His enhancement, presence of gastro - esophageal reflux of the contrast, and 2 patients have had the signs of axial cardial hiatal hernia. Simultaneously in $20.2 \%$ patients the symptoms of gastro -esophageal reflux disease with essential lowering of the patients' quality of life were observed.

Conclusion. LGP constitutes a potentially secure and effective bariatric operation, after which the body mass reduces significantly and constantly. But in 20.2\% patients the morbidity occur: through 12 mo after the operation GERD and reflux -esophagitis evolves. The origin of this late complications is a partial stenosis in the gastric angle region, what causes the development of prestenotic dilation of proximal gastric parts.

Keywords: obesity; matabolic syndrome; laparoscopic gastroplication; reflux -esophagitis. 
У більшості хворих морбідне ожиріння має резистентність до модифікації способу життя та медикаментозного лікування, лише менш ніж у 50\% пацієнтів можна досягти адекватного контролю глікемії на фоні сучасної фармакотерапіі. Саме тому була запроваджена метаболічна хірургія як метод боротьби з ожирінням та метаболічним синдромом та включена в протоколи лікування з довгостроковими комплаєнтними результатами [1]. Донедавна «золотим стандартом» баріатричної хірургії вважали гастрошунтування за Roux -en -Y. Однак в останні роки в лікуванні метаболічного синдрому віддають перевагу рестриктивним операціям, направленим на зменшення об'єму шлунка. Рукавна резекція (РP) шлунка є найбільш поширеним рестриктивним хірургічним втручанням у світі серед усіх метаболічних процедур. Показники ефективності втрати маси тіла, контролю діабету, частоти нічного апное та якості життя через 5 років після цієї операції відповідають результатам, отриманим після гастрошунтування за Roux -en -Y [2, 3]. Серед усіх баріатричних процедур, виконаних за період з 2014 по 2018 р., питома вага РР становила 45,9\% [4]. Однак багато дослідників повідомляють про розвиток проявів ГЕРХ та рефлюкс езофагіту у пацієнтів після рестриктивних метаболічних процедур [5 - 9].

У 2007 p. M. Talebpour та B. S. Amoli повідомили про лапароскопічну гастроплікацію (ЛГП) як новий метод у баріатричній хірургії [10]. ЛГП є рестриктивною процедурою, направленою на обмеження прийому їжі шляхом зменшення об'єму шлунка без його резекції, ЛГП є альтернативою РР у лікуванні ожиріння з подібним механізмом дії. Перевагою ЛГП є менша частота розвитку післяопераційних ускладнень, які потребують ревізійного хірургічного втручання, у порівнянні з РР $[11,12]$. Однак дана методика залишається маловивченою, отже, актуальні ії додаткові дослідження в контексті лікування ожиріння та метаболічного синдрому.

\section{Матеріали і методи дослідження}

Дослідження проведено на основі результатів обстеження та хірургічного лікування 79 хворих з ожирінням та метаболічним синдромом, яким виконали ЛгП на базах кафедр хірургії та судинної хірургії НМАПО імені П. Л. Шупика з 2015 по 2018 р. Чоловіків було 23, жінок - 56. Середній вік пацієнтів становив $(38,2 \pm 6,4)$ року. Обов'язковим критерієм включення пацієнтів до даного ретроспективного дослідження була відсутність у них проявів ГЕРХ, рефлюкс -езофагіту та органічної патології - грижі стравохідного отвору діафрагми (ГСОД), яка могла спричинити дані прояви в передопераційному та післяопераційному періодах.

Упродовж передопераційного періоду всім пацієнтам вимірювали антропометричні дані, а саме: зріст, масу тіла, індекс маси тіла (IMT), обвід живота та надлишок маси тіла (НМТ). Ступінь ожиріння оцінювали згідно з модифікованою Міжнародною федерацією хірургії ожиріння класифікацією ВООЗ за 1997 р.
Комплекс передопераційних інструментальних та клініко -лабораторних досліджень застосовували для виявлення супутніх та асоційованих з ожирінням захворювань. Діагноз метаболічного синдрому встановлювали відповідно до критеріїв ВООЗ 1999 р.

Для виключення наявності проявів ГЕРХ, рефлюкс езофагіту та органічної патології у передопераційному та післяопераційному періодах усім пацієнтам в обов'язковому порядку проводили анкетування за допомогою методики GerdQ та виконували фіброезофагогастродуоденоскопію (ФЕГДС), рентгеноскопію з контрастуванням верхніх відділів травного каналу.

Якість життя (ЯЖ) пацієнтів у передопераційному та післяопераційному періодах оцінювали за допомогою методики Moorehead - Ardelt II шляхом анкетування.

Усім пацієнтам, враховуючи їх вибір, показання та протипоказання до операції, була запропонована та виконана ЛГП. Також була надана інформація щодо можливих наслідків, ризиків та відповідних ускладнень. Дозвіл пацієнтів на проведення хірургічного лікування отримано.

Хворим на час перебування у стаціонарі в обов'язковому порядку були призначені нестероїдні протизапальні препарати, знеболювальні (дексалгін®), інгібітори протонної помпи (ІПП), глюкокортикоїди, антиеметики, якщо були скарги на блювання. Профілактику тромбоемболічних ускладнень проводили рутинно всім хворим відповідно до наказу МОЗ України №329 від 15.06.2007 p. (Клінічний протокол: Профілактика тромботичних ускладнень в хірургії, ортопедії і травматології, акушерстві та гінекологіi) та рекомендацій European Society of Anaesthesiology (ESA) (2017р.) низькомолекулярними гепаринами другого покоління, а саме беміпарином (цибор(®), дозування якого визначали за ступенем ризику, оцінюваним у балах перед оперативним втручанням. Також пацієнти продовжували приймати ІПП протягом місяця після проведеного хірургічного лікування. Пити хворі розпочинали через 30 - 60 хв після операції. Усім пацієнтам на 3 -тю добу після операції проводили рентгеноскопію з контрастуванням верхніх відділів травного каналу. Під час даного дослідження не спостерігали стенозу, витікання контрастної рідини за межі сформованої шлункової трубки, гастроезофагеального рефлюксу та вільної евакуації контрасту із шлунка. Усі пацієнти були проінформовані щодо дотримання рідкої дієти протягом трьох тижнів. Після чого вони поступово мали розширювати свій раціон дозованими порціями рідкої їжі.

У післяопераційному періоді досліджували ефективність та безпечність зазначеної метаболічної процедури. Основними критеріями ефективності були показники втрати НМТ, IMT, результати лабораторних досліджень (рівні тригліцеридів, холестерину, ліпопротеїдів низької та дуже низької щільності, індексу НОMА (Homeostasis Model Assesment), глікованого гемоглобіну, перебіг супутніх та асоційованих з ожирінням захворювань, метаболічні порушення, оцінка ЯЖ пацієнтів шляхом анкетування. Основними показниками безпечності вважали частоту і 
тяжкість ранніх та пізніх післяопераційних ускладнень. Післяопераційний перебіг цукрового діабету (Щд) 2 -го типу оцінювали відповідно до критеріїв Американської діабетичної асоціації (АДА) за 2009 р. Контрольні інструментальні, клініко -лабораторні дослідження та вимірювання антропометричних даних пацієнтів проводили на 1, 6 -му та 12 -му місяцях після операції.

опис хірургічної техніки

Пацієнт лежить на операційному столі в положенні антитренделенбурга під кутом 30. Оператор та перший асистент стоять праворуч від пацієнта, другий асистент - ліворуч. За допомогою голки Veress у точці Palmer накладаємо пневмоперитонеум (13 мм рт. ст.). У місцях інтервенції всіх троакарів виконуємо попередню інфільтрацію м'яких тканин 0,25\% розчином лонгокаїну. Встановлюємо п'ять троакарів у типових місцях за M. Talebpour. Інтраопераційно використовуємо орогастральний зонд діаметром 38 Fr 3 метою забезпечення декомпресії шлунка та створення достатнього його просвіту для формування шлункової трубки під час подальшої гастроплікації. Велику кривину шлунка мобілізуємо за допомогою біполярних затискачів, адаптованих до джерела високочастотної енергії апарата ЕК - 300М «Свармед» у режимі «зварювання ручне» 3 потужністю струму «45». Мобілізацію шлунка розпочинаємо від середньої третини його великої кривини та продовжуємо в дистальному напрямку, не доходячи на 4 см до воротаря, потім у проксимальному напрямку - до абдомінальної частини стравоходу. Після завершення мобілізації формуємо шлункову трубку шляхом інвагінації великої кривини шлунка. Накладаємо дворядний безперервний шов неабсорбуючим шовним матеріалом, прошиваючи задню стінку, інвагіновану велику кривину та передню стінку шлунка.

\section{Результати}

Середня маса тіла пацієнтів, залучених до даного дослідження, становила $(134,6 \pm 15,6)$ кг, середній IMT - (38 $\pm 6,5)$ кг $/ \mathrm{M}^{2}$, середній обвід живота - (126 \pm 12$)$ см. Серед наявних супутніх захворювань переважали захворювання серцево -судинної системи, виявлені у 55 пацієнтів, порушення ліпідного (у 48 пацієнтів) та вуглеводного (у 32 пацієнтів) обміну. Метаболічний синдром діагностували у 56 пацієнтів.

За результатами анкетування ніхто з пацієнтів не вказав на прояви ГЕРХ (0 балів за шкалою GerdQ). Під час проведення ФЕГДС даних про наявність ГСОД та рефлюкс -езофагіту у пацієнтів не отримали, у 18 пацієнтів була еритематозна гастропатія. Під час виконання контрастної рентгеноскопії відмічали нормотонічний, помірно збільшений у розмірах шлунок з вільною евакуацією контрасту в кишечник, без явищ стравохідного рефлюксу у разі зміни положення тіла. Лабораторне дослідження показало підвищення рівнів тригліцеридів, холестерину, ліпопротеїдів низької та дуже низької щільності у 48, індексу НОМА та глікованого гемоглобіну - у 32 пацієнтів. У 30 пацієнтів був џД 2 -го типу. Про показник ЯЖ, оцінений за ме- тодикою Moorehead - Ardelt II, судили за середнім значенням індексу ЯЖ перед операцією, який становив (1,3 $\pm 0,2)$ бала. Якісна оцінка числового значення зазначеного показника відповідала визначенням «дуже погано» та «погано» у 54 (68,3\%) пацієнтів.

Середня тривалість операції становила $(95 \pm 15,4)$ хв, загальні строки перебування пацієнтів у стаціонарі - від 2 до 5 днів, у середньому (3,2 \pm 1$)$ день.

У 10 пацієнтів після виконаної ЛГП виникло раннє післяопераційне ускладнення у вигляді тривалої нудоти та блювання (понад 24 год). Консервативною терапією дані прояви усунули.

Через рік після виконаної метаболічної процедури IMT і втрата НМТ у пацієнтів становили $(31,5 \pm 3,2)$ кг $/$ м $^{2}$ та 62,36\% відповідно.

За результатами повторних досліджень, проведених через рік після виконаного хірургічного втручання, визначили, що дана метаболічна процедура є ефективним методом лікування ожиріння, ЦД 2 -го типу, дисліпідеміі, гіпертонічної хвороби, тобто метаболічного синдрому. У 88,6\% пацієнтів відбулась компенсація артеріальної гіпертензії. Після ЛГП настала стійка ремісія Цд 2 -го типу у 73,9\% пацієнтів. Корекцію дисліпідемії спостерігали у $41,5 \%$ хворих.

Повторним анкетуванням через 12 міс за допомогою методики Moorehead - Ardelt II зафіксували покращення ЯЖ, про що свідчило збільшення індексу ЯЖ до (2,0 $0,4)$ бала.

Однак 20,2\% пацієнтів, котрі брали участь у ретроспективному дослідженні, під час повторного анкетування за допомогою методики GerdQ (проміжок від 9 до 11 балів) вказували на прояви ГЕРХ, що значно погіршувало їм ЯЖ. За даними контрольного проведення ФЕГДС через рік після ЛГП у 16 (20,2\%) пацієнтів виявили de novo ознаки рефлюкс -езофагіту (у 14 - ступінь тяжкості А, у 2 - ступінь тяжкості В відповідно до Лос -Анджелеської класифікаціi), розширення нижнього стравохідного сфінктера. За даними проведеної повторної рентгеноскопії 3 контрастуванням верхніх відділів травного каналу через 6 міс після ЛГП у 20 (25,3\%) пацієнтів констатували нерівномірне звуження шлункової трубки вище кута шлунка. Через 12 міс спостерігали рентгенологічні ознаки значного розширення сформованої шлункової трубки, дна та кардіального відділу шлунка, збільшення кута Гіса, гастроезофагеальний рефлюкс контрастної рідини, а у 2 пацієнтів ознаки аксіальної кардіальної ГСОД, для корекції якої застосували консервативну терапію. Однак у обох цих пацієнтів медикаментозна терапія виявилась неефективною, внаслідок чого їм була запропонована та виконана хірургічна корекція даного патологічного стану (згоду отримано). Враховуючи значне розширення проксимальних відділів шлунка, виконали лапароскопічне доповнення гастроплікації, застравохідну крурорафію ніжок діафрагми та фундоплікацію за Ніссеном. Через рік після повторного хірургічного лікування у пацієнтів не спостерігали клінічних, ендоскопічних та рентгенологічних ознак ГЕРХ. 


\section{Обговорення}

Рестриктивні операції, до яких належить і ЛГП, позитивно впливають на зниження маси тіла пацієнтів та динаміку перебігу у них супутніх захворювань впродовж короткострокового та довгострокового післяопераційного періоду [13]. Однак після більшості рестриктивних операцій розвивається гастроезофагеальний рефлюкс у довгостроковому післяопераційному періоді та внаслідок цього значно знижується показник ЯЖ пацієнтів після проведеного хірургічного лікування [14, 15], що в подальшому потребує застосування медикаментозної терапії або проведення повторного хірургічного лікування з метою корекції даного патологічного стану. Враховуючи це, актуально та необхідно здійснювати пошук нових методів хірургічного лікування ожиріння та метаболічного синдрому або модифікувати існуючі процедури з метою попередження виникнення та розвитку зазначених віддалених ускладнень, підвищення ефективності хірургічного лікування з покращенням показника ЯЖ пацієнтів у віддалені строки після виконаної баріатричної процедури.

\section{Висновки}

ЛГП є потенційно безпечною та ефективною операцією, після якої значно і стійко знижується МТ. Однак у 20,2\% пацієнтів розвиваються віддалені ускладнення - ГЕРХ та рефлюкс -езофагіт - впродовж 12 міс після виконаної ЛГП з метою хірургічного лікування ожиріння. На нашу думку, виникнення зазначених віддалених ускладнень є наслідком часткового стенозу в ділянці кута шлунка, що призводить до розвитку престенотичного розширення його проксимальних відділів. У подальшому через дане розширення згладжується кут Гіса, формується аксіальна кардіальна ГСОД та втрачається змикання нижнього стравохідного сфінктера. Для виявлення цього ускладнення необхідно проводити подальші дослідження, здійснювати пошук можливих способів його усунення та попередження у короткостроковому та довгостроковому періодах після виконаної метаболічної процедури, що в подальшому покращить ЯЖ пацієнтів. Можливим розв'язанням даної проблеми може бути виконання першочергової симультанної операції фундогастроплікації, що включає одномоментне виконання ЛГП та фундоплікації з метою лікування метаболічного синдрому та попередження виникнення ГЕРХ.

\section{Підтвердження}

Фінансування. За власні кошти.

Інформація про внесок кожного учасника. Саволюк С. I. - ідея та концепція дослідження; Лисенко B. М., Крестянов М. Ю. - практичне виконання; Завертиленко Д. С., Глаголєва А. Ю., Кругляк Є. К. - періопераційний супровід, накопичення бази даних, іiі аналіз, статистичне опрацювання, оформлення роботи.

Конфлікт інтересів. Автори декларують відсутність конфлікту інтересів.

Згода на публікацію. Всі автори дали згоду на публікацію цього рукопису.

\section{References}

1. Gary Yee Ang. Reversibility of diabetes mellitus: Narrative review of the evidence. World J Diabetes. 2018;9(7):127 -31. doi: 10.4239/wjd. v9.i7.127.

2. Peterli R, Wölnerhanssen BK, Peters T, Vetter D, Kröll D, Borbély Y, et al. Effect of laparoscopic sleeve gastrectomy vs laparoscopic Roux -en -Y gastric bypass on weight loss in patients with morbid obesity: the SM -BOSS randomized clinical trial. JAMA. 2018;319(3):255 -65. doi: 10.1001/jama.2017.20897.

3. Salminen P, Helmiö M, Ovaska J, Juuti A, Leivonen M, Peromaa Haavisto P, et al. Effect of laparoscopic sleeve gastrectomy vs laparoscopic Roux -en -Y gastric bypass on weight loss at 5 years among patients with morbid obesity: the SLEEVEPASS randomized clinical trial. JAMA. 2018;319(3):241 -254. doi: 10.1001/jama.2017.20313.

4. Welbourn R, Hollyman M, Kinsman R, Dixon J, Liem R, Ottosson J, et al. Bariatric Surgery Worldwide: Baseline Demographic Description and One -Year Outcomes from the Fourth IFSO Global Registry Report 2018. Obes Surg. 2019;29(3):782 -795. doi: 10.1007/s11695 $-018-3593-1$.

5. Himpens J, Dapri G, Cadière GB. A prospective randomized study between laparoscopic gastric banding and laparoscopic isolated sleeve gastrectomy: results after 1 and 3 years. Obes Surg. 2006;16:1450-6. doi: 10.1381/096089206778869933.

6. Pallati PK, Shaligram A, Shostrom VK, Oleynikov D, McBride CL, Goede MR. Improvement in gastroesophageal reflux disease symptoms after various bariatric procedures: review of the Bariatric Outcomes Longitudinal Database. Surg Obes Relat Dis. 2014;10:502 -7. doi: 10.1016/j. soard.2013.07.018.

7. Arias E, Martínez PR, Ka Ming Li V, Szomstein S, Rosenthal RJ. Mid -term follow - up after sleeve gastrectomy as a final approach for morbid obesity. Obes Surg. 2009;19:544 -548. doi: 10.1007/s11695-009 $-9818-6$.

8. Braghetto I, Csendes A, Korn O, Valladares H, Gonzalez P, Henríquez A. Gastroesophageal reflux disease after sleeve gastrectomy. Surg Laparosc Endosc Percutan Tech. 2010;20:148 -53. doi: 10.1097/ SLE.0b013e3181e354bc.

9. Braghetto I, Lanzarini E, Korn O, Valladares H, Molina JC, Henriquez A. Manometric changes of the lower esophageal sphincter after sleeve gastrectomy in obese patients. Obes Surg. 2010;20:357 -62. doi: 10.1007/ s11695-009-0040 -3.

10. Talebpour M, Amoli BS. Laparoscopic total gastric vertical plication in morbid obesity. J Laparoendosc Adv Surg Tech A. 2007 Dec;17(6):793 -8.doi:10.1186/1750-1164-6-7.

11. Verdi D, Prevedello L, Albanese A, Lobba A, Foletto M. Laparoscopic gastric plication (LGCP) vs sleeve gastrectomy (LSG): a single institution experience. Obes Surg. 2015;25:1653-7. doi: 10.1007/s11695 $-015-1600-3$.

12. Zerrweck C, Rodríguez JG, Aramburo E, Vizcarra R, Rodríguez JL, Solórzano A, et al. Revisional surgery following laparoscopic gastric plication. Obes Surg. 2017;27:38-43. doi: 10.1007/s11695 -016-2242 -9.

13. Burgmer R1, Legenbauer T, Müller A, de Zwaan M, Fischer C, Herpertz S. Psychological outcome 4 years after restrictive bariatric surgery. Obes Surg. 2014;24(10):1670 -8. doi: 10.1007/s11695-014-1226-X.

14. Fabien Stenard, Antonio Iannelli. Laparoscopic sleeve gastrectomy and gastroesophageal reflux. World J Gastroenterol. 2015;21(36):10348-57. doi: 10.3748/wjg.v21.i36.10348.

15. Iswanto Sucandy, Dewi Chrestiana, Fernando Bonanni, Gintaras Antanavicius. Gastroesophageal reflux symptoms after laparoscopic sleeve gastrectomy for morbid obesity. The importance of preoperative evaluation and selection. N Am J Med Sci. 2015;7(5):189-93. doi: 10.4103/1947-2714.157624.

Надійшла 12.03.19 